\title{
EDITORIAL
}

\section{Concepções de lirismo: as múltiplas vozes dos poetas}

Este volume 15 da Revista Texto Poético apresenta, como no número anterior, uma divisão: o "Dossiê Concepções de Lirismo e a "Vária”. Os artigos do dossiê abordam diferentes poetas e pontos de vista diversos sobre o lirismo.

Em 0 cisne noutros lugares ou da impossibilidade de esquecer a dor, Orlando Nunes de Amorim aponta, a partir da leitura de $O$ Cisne, de Baudelaire, para a existência de uma dupla dor que faz latejar a subjetividade do melancólico: "a dor do exílio, da felicidade perdida, e também a dor da impossibilidade de esquecer a dor, porque o sujeito melancólico não pode escapar do desejo de, como todo mundo, ser feliz, e mais do que isso, de dar um sentido à sua existência”. No artigo, o autor recupera algumas linhas mestras da poética baudelairiana para ancorar a discussão no que, talvez, seja o cerne dela: a melancolia.

Em a Imaginação como metafísica: uma leitura de Percurso de um particular de Wallace Stevens, Alcides Cardoso dos Santos destaca a relação entre imaginação e realidade que permeia a obra de Stevens. Como ressalta o autor em seu artigo: "Expurgando dela [da obra] os resquícios românticos subjetivizantes e dotando-a de capacidade de abstração e generalização, Stevens lhe dá envergadura de ontologia, na medida em que ela possibilita ao poeta tanto a apreensão das particularidades do mundo real quanto o desenvolvimento do pensamento lógico em direção a uma fenomenologia da percepção".

Em Vinicius de Moraes: Do Amor e Outras Mutações..., André 
Dias ressalta a importância da avaliação da poética de Vinicius de Moraes a partir da consideração de três perspectivas temáticas: a poesia lírica-amorosa, a de cunho social e aquela voltada para a meditação existencial. Desse modo, ampliando a leitura que usualmente se faz do poeta, bastante calcada na poesia amorosa, Dias mostra a singularidade e diversidade da obra, afirmando que "mutação é a palavra que melhor define Vinicius de Moraes", tanto no que diz respeito ao trânsito entre vida pública e privada, quanto no que concerne aos desdobramentos temáticos de sua poesia nos aspectos acima mencionados.

Em 0 Ethos do Jardim de Dora Ribeiro, Rauer Rodrigues e Kelcilene Grácia Rodrigues apresentam o ethos singular que permeia o projeto poético de Dora Rodrigues, marcado por poemas que edificam o eu lírico na mesma medida em que, na aparência, se recusam a expor o sujeito biográfico. Como dizem os autores, "seus versos, entre o simples e o inusitado, evidenciam a reflexão existencial e metapoética que norteia a feitura do discurso" da poeta, cuja voz vem se afirmando como uma das mais singulares da poesia brasileira contemporânea.

Wilberth Salgueiro em A poesia brasileira lida numa antologia: exercícios de solidão realiza uma reflexão, a partir da Antologia comentada da poesia brasileira do século 21, de Manoel da Costa Pinto, apontando para a prevalência de uma "estética de efeitos" que permeia as diferentes vozes que a obra apresenta. Ao final, com muita acuidade, o autor ressalta que entre os poetas contemporâneos "parece haver um temor generalizado por fazer uma poesia que se contamine de história, de reflexões sociais, de algo que lembre 'engajamento', conceito e prática que foram expurgados do vocabulário e das atitudes de poetas e cidadãos, cada vez mais ilhados entre quatro vetores: 1) o sujeito importa mais que o coletivo, 2) a solidão que a solidariedade, 3) os meios estéticos autorreferenciais valem mais que uma poesia que leve à reflexão, 4) o efeito e a contemplação valem mais do que qualquer ação".

Em 0 aspecto tendencial da negatividade como linha de força da poesia moderna em Dulce María Loynaz, Yoanky Cordero Goméz 
elabora uma reflexão sobre a permanência da negatividade, tal qual a define Friedrich, na poética de Dulce María, apontando para a relação entre o caráter negativo de suas obras e os questionamentos existenciais que se manifestam, em ambas, sobretudo, pelo silêncio; como destaca o autor: "podemos dizer que esta poética do silencio é uma alternativa para quem, como as poetas, percorreram vastas zonas da linguagem. O silencio é a abstenção da fala ou da não-fala e mesmo nesse ponto aparece outra via, aquela onde o silencio acolhe a palavra latente, aquela que ainda está se para dizer, para escrever".

Parece, portanto, que a melancolia que Orlando Nunes de Amorim sublinha no primeiro artigo do dossiê ecoa, ainda, entre os poetas brasileiros contemporâneos, mas, ao contrário do espanto do poeta francês diante das mudanças à sua volta e da tentativa de elaborálas poeticamente seja pela recusa, seja pela constatação da realidade que circunda o sujeito lírico, a poesia brasileira contemporânea, aqui analisada, parece evitar a relação direta entre o poeta e seu tempo. Entre o primeiro e o último artigos do dossiê, gradações poéticas sublinham concepções de lirismo que se sustentam nas necessárias relações entre imaginação e realidade e apontam linhas de força que parecem ser próprias de um lirismo que talvez esteja em busca de novas configurações, daí, talvez, a exacerbação da metapoesia e da metalinguagem. Evidentemente, este pequeno dossiê não esgota a discussão sobre "concepções de lirismo", mas certamente aponta para aspectos sobre os quais o estudioso da poesia poderá se debruçar.

Em Vária, apresentamos, nesta edição, dois textos que contribuem para a reflexão sobre poesia sob dois aspectos distintos. 0 primeiro, de Andrea Kouklanakis, intitulado Algumas considerações sobre a tradução de Finismundo para o inglês faz uma discussão sobre a tradução para o inglês do poema haroldiano. A partir da discussão, a autora evidencia o trabalho com a linguagem e a retomada da tradição feita por Haroldo.

Em Líricas contemporâneas: Apontamentos para uma 
revocalização do logos, Leonardo Davino de Oliveira discute o emudecimento poético a partir das relações entre poesia, vocalização e música popular brasileira. Como aponta o autor, "o ponto central da questão não é a desvalorização da escrita, ou sua negação, mas observar os contatos, as intersecções e os pontos de mutação entre a palavra falada e a palavra escrita. Importa ouvir o logos não para 'entendê-lo' (racionalmente), mas para, a partir dele, escolher caminhos. Ou seja, questionar a ordem que regula a conexão entre as palavras e se deixar envolver com a 'força bruta': ser criação ao ritmo do plano acústico da palavra".

Por fim, contribui com estevolumeSusanna Busato coma apresentação da resenha "Jean-Pierre Lemeire: poesia em suspensão". 0 poeta está ao alcance do leitor brasileiro em tradução de Júlio Castañon Guimarães e certamente será apreciado por sua obra que entrelaça beleza e simplicidade. Como ressalta a autora em sua resenha, "a lírica de JeanPierre Lemaire é imagética, e, como voz, suspensa no tempo, fluida e espectral. E só tem voz e cor, volume e contorno, quando encontra nos objetos sua realidade temporal: olhar que se alimenta de possíveis; memória espacializada naquilo que o sujeito elege como sopro de si mesmo: palavra objetiva e compromissada com seu poder imagético".

Esperamos que o presente volume da Texto Poético possibilite ao leitor momentos de reflexão segura sobre o lirismo, suas linhas de força e diálogos, especialmente com a música popular.

Boa leitura!

Diana Junkes Bueno Martha Ida Alves 